\title{
Selective Kirchner medium in the culture of specimens other than sputum for mycobacteria
}

\author{
DA MITCHISON, BW ALLEN, DEVI MANICKAVASAGAR
}

From the Department of Bacteriology, Royal Postgraduate Medical School, Ducane Road, London, W12 OHS

SUMMARY Over a two-year period, 2949 non-sputum specimens were cultured on two slopes of Löwenstein-Jensen (LJ) medium, two bottles of Kirchner liquid medium, made selective by adding polymyxin $\mathrm{B}$, carbenicillin, trimethoprim and amphotericin $\mathrm{B}$, and a selective $7 \mathrm{H} 11$ agar slope. Pus and CSF were inoculated into this set without prior treatment, but other specimens were decontaminated with sulphuric acid. Tissues and fluids were also inoculated without decontamination into additional selective media. The use of the selective media as well as the $\mathrm{LJ}$ slopes increased the yield of specimens with cultures of tubercle bacilli from 34 to 53 and decreased specimens with all media contaminated from 34 to 2 . Results almost as good, 52 positive specimens and five totally contaminated, would have been obtained by the addition of a single selective Kirchner bottle to the two LJ slopes, and this is recommended for routine use.

The culture of specimens other than sputum for tubercle bacilli and other mycobacteria is an appreciable part of the work of any microbiology laboratory, particularly in areas housing immigrants from the Indian subcontinent with their high incidence of non-respiratory tuberculosis. ${ }^{12}$ Many of these specimens, such as tissues, pus obtained at operation and fluids from the chest or joints, are usually only obtained once and must therefore be examined as thoroughly as possible to give the maximum chance of isolating mycobacteria. In the past this was often achieved by guinea-pig inoculation, in which the animals were injected with considerably larger volumes of material than could be inoculated onto slopes of solid culture medium. Small numbers of contaminatory organisms in the inoculum were killed by the immune responses of the animal. While routine guinea-pig inoculation can no longer be recommended because of its high cost, the increasing stringency of safety legislation, the current climate of opinion against animal experimentation and the efficiency of culture methods, ${ }^{34}$ its advantages can be equalled or improved upon by the use of liquid medium made selective by the incorporation of antibiotics. ${ }^{56}$ Large volumes of material can be cultured in liquid media without inhibiting the growth of tubercle bacilli and the selective antibiotics are effective in reducing contamination. Indeed,

Accepted for publication 27 July 1983 so effective are the antibiotics that they are of great value in reducing the eventual contamination rate in cultures inoculated with specimens, such as urines and faeces, which contain heavy loads of contaminatory organisms. ${ }^{6}$

In an earlier study on the culture of 2540 specimens other than sputum, the addition of two bottles of selective Kirchner medium to the usual two slopes of Löwenstein-Jensen medium, one with and one without pyruvate, increased the number of specimens yielding positive cultures from 45 to $55 .^{6}$ More recently, the same addition increased the number of operation specimens from patients with spinal tuberculosis yielding Mycobacterium tuberculosis from 75 to $141 .^{7}$ The value of selective slopes of $7 \mathrm{H} 11$ oleic acid-albumin agar medium is uncertain, as it appeared more efficient than Kirchner medium in one study ${ }^{4}$, but no more useful than LöwensteinJensen medium in two others. ${ }^{67}$ We report here a study on all of the 2949 specimens other than sputum cultured for myobacteria over a two-year period from April, 1980 to April, 1982 at Hammersmith Hospital. All specimens were cultured on Löwenstein-Jensen medium slopes, selective 7H11 medium slopes and in selective Kirchner liquid medium. Specimens of cerebrospinal fluid and pus were cultured without acid treatment. Urine and faeces specimens were always decontaminated lightly with $\mathrm{H}_{2} \mathrm{SO}_{4}$ before culture. Other specimens were divided into two portions, one cultured without 
acid treatment and the other cultured after acid decontamination.

\section{Material and methods}

\section{MEDIA}

The culture media used were Löwenstein-Jensen slopes without potato starch $(\mathrm{LJ}),{ }^{8} \mathrm{LJ}$ slopes containing $0.5 \%$ sodium pyruvate $(\mathrm{LJ}+\mathrm{P}), 7 \mathrm{H} 11$ oleic acid-albumin slopes with malachite green (Difco Laboratories, Central Avenue, West Molesey, Surrey; code 0838) and Kirchner medium with the following formula:

$\begin{array}{lr}\mathrm{Na}_{2} \mathrm{HPO}_{4} .12 \mathrm{H}_{2} \mathrm{O} & 19 \mathrm{~g} \\ \mathrm{KH}_{2} \mathrm{PO}_{4} & 2 \mathrm{~g} \\ \mathrm{MgSO}_{4} \cdot 7 \mathrm{H}_{2} \mathrm{O} & 0.6 \mathrm{~g} \\ \mathrm{Na}_{3} \mathrm{C}_{6} \mathrm{H}_{5} \mathrm{O}_{7} .2 \mathrm{H}_{2} \mathrm{O} & 2.5 \mathrm{~g} \\ \mathrm{~L}-\text { asparagine } & 5 \mathrm{~g} \\ \text { Glycerol } & 20 \mathrm{ml} \\ 0.4 \% \text { phenol red } & 3 \mathrm{ml} \\ \text { Distilled water } & \text { to } 1 \mathrm{l}\end{array}$

pH 6.9 - 7.2

This medium was prepared from Oxoid dried powder, as in an earlier study; ${ }^{4}$ it is no longer available from Oxoid though it can be obtained as complete medium with antibiotics from Difco Laboratories (code 9306-97). For the present study, the following additions, used earlier, ${ }^{6}$ were made:

Casein hydrolysate (Oxoid tryptone, L42) $0.5 \mathrm{~g} / 1$

$10 \%$ calf serum in place of horse serum

The $7 \mathrm{H} 11$ and Kirchner media were made selective by the addition of polymyxin B $200 \mathrm{units} / \mathrm{ml}$, carbenicillin $100 \mathrm{mg} / \mathrm{l}$, trimethoprim $10 \mathrm{mg} / \mathrm{l}$ and amphotericin B $10 \mathrm{mg} / \mathrm{l}$ [5]. All media were dispensed in wide-mouthed, screw-capped (universal) $28 \mathrm{ml}$ bottles, the slopes in $5 \mathrm{ml}$ and the Kirchner liquid medium in $10 \mathrm{ml}$ amounts.

\section{TREATMENT OF SPECIMENS}

Except when stated to the contrary, the volumes of a specimen added to the media were two loopfuls (about $0.02 \mathrm{ml}$ ) onto $\mathrm{LJ}, \mathrm{LJ}+\mathrm{P}$ and selective $7 \mathrm{H} 11$ (S7H11) slopes, a small inoculum of three drops $(0.1 \mathrm{ml})$, into a tube of selective Kirchner medium (SKS) and the remainder, a large inoculum of about $0.8 \mathrm{ml}$, into a second bottle of selective Kirchner medium (SKL). Cerebrospinal fluid (CSF) was centrifuged at $3000 \mathrm{rpm}$ for $15 \mathrm{~min}$ and the supernatant added to one bottle of selective Kirchner medium. From the deposit, one loopful was added to each of the three slopes and the remainder added to a second Kirchner bottle. Pus and pus swabs were also put on the media without acid decontamination as described above, except that the SKL bottle was inoculated with the broken-off tip of the swab.
Urine specimens, usually early morning collections, were allowed to sediment. About $20 \mathrm{ml}$ of sediment was transferred to each of three universal containers $\underline{ }$ and centrifuged. The pooled deposits were treated with $5 \% \mathrm{H}_{2} \mathrm{SO}_{4}(\mathrm{vol} / \mathrm{vol})$ for $15 \mathrm{~min}$, washed with $\stackrel{0}{?}$ sterile water and suspended in $1 \mathrm{ml}$ water before $\bar{C}$ being inoculated on the media. Faeces were extracted with ether and the interface treated with $\frac{\bar{s}}{\vec{\sigma}}$ acid before culture. Tissues were disintegrated and $\stackrel{\mathbb{D}}{\square}$ suspended in $2 \mathrm{ml}$ sterile water. Fluids were cen- क trifuged and the deposit resuspended in $2 \mathrm{ml}$ water. Of the $2 \mathrm{ml}$ tissue suspension or fluid deposit, $1 \mathrm{ml}$. was acid-treated as for the urines and the other $1 \mathrm{ml}$ was inoculated without acid treatment onto S7H11, SKS and SKL media only.

\section{CULTURE}

Cultures were examined at weekly intervals for a total of seven weeks. If microcolonies were seen in the SKS or SKL bottles or if no growth was seen at five weeks, they were subcultured onto LJ slopes 은 which were then incubated until growth occurred or until seven weeks. Cultures were identified as $M$ tuberculosis by examining Ziehl-Neelsen stained bacilli for acid-fastness and testing for niacin production. Sensitivity tests by standard MRC methods were then set up to isoniazid and streptomycin, ${ }^{9}$ and to rifampicin. ${ }^{10}$

\section{Results}

\section{TYPES OF SPECIMEN}

Of the total of 2949 specimens examined over the $\stackrel{\mathbb{Q}}{\circ}$ two-year period, $1327(45.0 \%)$ were urines, 903 궁 $(30.6 \%)$ chest and other fluids, $332(11.3 \%)$ tissues, 3 $230(7.8 \%)$ cerebrospinal fluids mainly from babies, $131(4.4 \%)$ pus and pus swabs and $26(0.9 \%)$ faeces (Table 1). Lymph glands and pus or pus swabs were most often positive by direct smear $(8.9 \%$ and $7.6 \%$, respectively) and by culture $(17.9 \%$ and $13.7 \%$ ), while other tissues and chest fluids were less often positive and the remaining types, comprising the majority of the specimens, were seldom positive. In all, a positive smear was found in $22(0.7 \%)$ of the 2949 specimens. A culture of $M$ tuberculosis $\frac{7}{0}$ was obtained from $52(1.8 \%)$ specimens and strain BCG from one pus swab. No other species of $N$ mycobacteria were isolated. Resistance to isoniazid N was found in six cultures of $M$ tuberculosis, resis- N tance to streptomycin in seven cultures, but resistance to rifampicin was never encountered.

The contamination rate was highest in cultures of $\stackrel{\bullet}{\mathscr{C}}$ pus and pus swabs, none of which were treated with $\mathscr{\Phi}$ acid; $22(16.8 \%)$ of 131 specimens were contaminated on any medium, but all media were contami- 
Table 1 Bacteriological results by specimen type

\begin{tabular}{|c|c|c|c|c|c|c|c|c|c|c|c|c|}
\hline \multirow{2}{*}{$\begin{array}{l}\text { Type of } \\
\text { specimen }\end{array}$} & \multirow{2}{*}{$\begin{array}{l}\text { Treatment } \\
\text { of specimen }\end{array}$} & \multirow{2}{*}{$\begin{array}{l}\text { Total } \\
\text { specimens } \\
(A)\end{array}$} & \multirow{2}{*}{\multicolumn{2}{|c|}{$\begin{array}{l}\text { Smear } \\
\text { positive } \\
\text { No \% of } A\end{array}$}} & \multirow{2}{*}{\multicolumn{2}{|c|}{$\begin{array}{l}\text { Culture } \\
\text { positive } \\
\text { No \% of } A\end{array}$}} & \multicolumn{6}{|c|}{ Contaminated on: } \\
\hline & & & & & & & $\begin{array}{l}\text { Any } \\
\text { med } \\
\text { No }\end{array}$ & \% of $A$ & $\begin{array}{l}\text { Three } \\
\text { media } \\
\text { No }\end{array}$ & $\begin{array}{l}\text { or more } \\
\% \text { of } A\end{array}$ & $\begin{array}{l}\text { All } \\
\text { media } \\
\text { No }\end{array}$ & $\%$ of $A$ \\
\hline $\begin{array}{l}\text { Cerebrospinal fluid } \\
\text { Pus and pus swab }\end{array}$ & None & $\begin{array}{l}230 \\
131\end{array}$ & $\begin{array}{r}1 \\
10\end{array}$ & $\begin{array}{l}0 \cdot 4 \\
7 \cdot 6\end{array}$ & $\begin{array}{r}1 \\
18\end{array}$ & $\begin{array}{r}0 \cdot 4 \\
13 \cdot 7\end{array}$ & $\begin{array}{r}0 \\
22\end{array}$ & $\begin{array}{r}0 \cdot 0 \\
16 \cdot 8\end{array}$ & $\begin{array}{l}0 \\
5\end{array}$ & $\begin{array}{l}0 \cdot 0 \\
3 \cdot 8\end{array}$ & $\begin{array}{l}0 \\
2\end{array}$ & $\begin{array}{l}0 \cdot 0 \\
1 \cdot 5\end{array}$ \\
\hline $\begin{array}{l}\text { Urine } \\
\text { Faeces }\end{array}$ & $\mathrm{H}_{2} \mathrm{SO}_{4}$ & $\begin{array}{r}1327 \\
26\end{array}$ & $\begin{array}{l}1 \\
0\end{array}$ & $\begin{array}{l}0 \cdot 1 \\
0 \cdot 0\end{array}$ & $\begin{array}{l}2 \\
0\end{array}$ & $\begin{array}{l}0 \cdot 2 \\
0 \cdot 0\end{array}$ & $\begin{array}{l}3 \\
3\end{array}$ & $\begin{array}{l}0 \cdot 2 \\
0 \cdot 0\end{array}$ & $\begin{array}{l}1 \\
0\end{array}$ & $\begin{array}{r}0 \cdot 1 \\
11 \cdot 5\end{array}$ & $\begin{array}{l}0 \\
0\end{array}$ & $\begin{array}{l}0 \cdot 0 \\
0 \cdot 0\end{array}$ \\
\hline $\begin{array}{l}\text { Lymph gland } \\
\text { Other tissue } \\
\text { Chest fluid } \\
\text { Other fluid } \\
\text { Total }\end{array}$ & $\begin{array}{c}\text { None } \\
\text { or } \\
\mathrm{H}_{2} \mathrm{SO}_{4}\end{array}$ & $\begin{array}{r}56 \\
276 \\
391 \\
512 \\
2949\end{array}$ & $\begin{array}{r}5 \\
2 \\
3 \\
0 \\
22\end{array}$ & $\begin{array}{l}8.9 \\
0.7 \\
0.8 \\
0.0 \\
0.7\end{array}$ & $\begin{array}{r}10 \\
9 \\
9 \\
4 \\
53\end{array}$ & $\begin{array}{r}17 \cdot 9 \\
3 \cdot 3 \\
2 \cdot 3 \\
0 \cdot 8 \\
1 \cdot 8\end{array}$ & $\begin{array}{r}1 \\
12 \\
7 \\
6 \\
54\end{array}$ & $\begin{array}{l}1.8 \\
4.3 \\
1.8 \\
1.2 \\
1.8\end{array}$ & $\begin{array}{r}1 \\
6 \\
3 \\
0 \\
16\end{array}$ & $\begin{array}{l}1 \cdot 8 \\
2 \cdot 2 \\
0 \cdot 8 \\
0 \cdot 0 \\
0 \cdot 5\end{array}$ & $\begin{array}{l}0 \\
0 \\
0 \\
0 \\
2\end{array}$ & $\begin{array}{l}0 \cdot 0 \\
0 \cdot 0 \\
0 \cdot 0 \\
0 \cdot 0 \\
0 \cdot 1\end{array}$ \\
\hline
\end{tabular}

nated in only two specimens. It is remarkable that these were the only two $(0 \cdot 1 \%)$ of the total of 2949 specimens that were contaminated on all media. Specimens such as urines and faeces, that are usually considered to have high contamination rates even after acid treatment, rarely yielded contaminated media; only six $(0.4 \%)$ of 1353 specimens were contaminated on any medium and none on all media.

\section{RELATIVE EFFICIENCY OF CULTURE MEDIA}

The relative efficiencies of the culture media were considered separately in specimens that were inoculated without acid decontamination, in those that were only inoculated after acid treatment and in those inoculated before and after acid decontamination (Table 2). The S7H11 slopes did little better than the $\mathrm{LJ}$ and $\mathrm{LJ}+\mathrm{P}$ slopes in either untreated CSF and pus or in acid treated tissues and fluids. In the untreated CSF and pus specimens, cultures were obtained about twice as often in the SKS and SKL media (17 and 19 positives, respectively) as on $\mathrm{LJ}$ and $\mathrm{LJ}+\mathrm{P}$ slopes ( 9 and 8 positives, respectively). The difference between positivity on LJ and SKS was significant (specimens positive on LJ only 0 , SKS only $8, p<0.005$ ), as was the difference between LJ and SKL (LJ only 0, SKL only 9, $p<0.005$ ). A similar substantial advantage of the SKS and SKL liquid media as compared to the slopes was seen in the tissues and fluids irrespective of whether preliminary acid treatment had been used, the Kirchner media yielding about double the number of positive cultures. In these, all of the comparisons between S7H11 and SKS or SKL media in untreated specimens and between LJ and SKS or SKL media in acid treated specimens were statistically significant $(p<0.05)$. Treatment with acid had little effect on the number of positive cultures though the largest number of tissues and fluids yielding $M$ tuberculosis (31) was obtained in SKL medium without previous acid decontamination.

The numbers of specimens that yielded a contaminated culture on the various media are set out in

Table 2 Numbers of cultures of tubercle bacilli obtained on various media

\begin{tabular}{|c|c|c|c|c|c|c|c|c|c|c|}
\hline \multirow[t]{2}{*}{ Type of specimen } & \multicolumn{5}{|c|}{ Untreated with $\mathrm{H}_{2} \mathrm{SO}_{4}$} & \multicolumn{5}{|c|}{ Treated with $\mathrm{H}_{2} \mathrm{SO}_{4}$} \\
\hline & $L J$ & $L J+P$ & $S 7 H 11$ & $S K S$ & $S K L$ & $L J$ & $L J+P$ & $S 7 H I I$ & $S K S$ & $S K L$ \\
\hline CSF, Pus & $9^{*}$ & $8^{*}$ & 11 & 17 & $19 \dagger$ & - & - & - & - & - \\
\hline Urine, faeces & - & - & - & - & - & 1 & 1 & 1 & 1 & 1 \\
\hline Tissue, fluid & - & - & 14 & 28 & 31 & 17 & 16 & 19 & 25 & 28 \\
\hline
\end{tabular}

* Two specimens contaminated on $\mathrm{L}$ and $\mathrm{LJ}+\mathrm{P}$, but positive on other media.

+ One specimen positive only on subculture.

Table 3 Contaminated cultures on various media

\begin{tabular}{|c|c|c|c|c|c|c|c|c|c|c|}
\hline \multirow[t]{2}{*}{ Type of specimen } & \multicolumn{5}{|c|}{ Untreated with $\mathrm{H}_{2} \mathrm{SO}_{4}$} & \multicolumn{5}{|c|}{ Treated with $\mathrm{H}_{2} \mathrm{SO}_{4}$} \\
\hline & $L J$ & $L J+P$ & $S 7 H 11$ & $S K S$ & $S K L$ & $L J$ & $L+P$ & $S 7 H 11$ & $S K S$ & $S K L$ \\
\hline $\begin{array}{l}\text { CSF, Pus } \\
\text { Urine, faeces } \\
\text { Tissue, fluid }\end{array}$ & $\frac{21}{-}$ & $\frac{20}{-}$ & $\frac{3}{7}$ & $\frac{2}{14}$ & $\frac{5}{14}$ & $\begin{array}{r}-4 \\
14\end{array}$ & $\begin{array}{r}-4 \\
14\end{array}$ & $\begin{array}{l}\overline{0} \\
0\end{array}$ & $\begin{array}{l}- \\
2 \\
0\end{array}$ & $\begin{array}{l}- \\
0\end{array}$ \\
\hline
\end{tabular}


Table 4 Specimens yielding positive or contaminated cultures on various combinations of media

\begin{tabular}{|c|c|c|c|c|}
\hline \multirow[t]{3}{*}{ Media } & \multirow{2}{*}{\multicolumn{2}{|c|}{$\begin{array}{l}\text { Specimens with positive cultures } \\
\text { on any medium }\end{array}$}} & \multicolumn{2}{|c|}{ Contaminated cultures: } \\
\hline & & & \multirow{2}{*}{$\begin{array}{l}\text { On any } \\
\text { medium }\end{array}$} & \multirow{2}{*}{$\begin{array}{l}\text { On all } \\
\text { media }\end{array}$} \\
\hline & No & $\%$ & & \\
\hline $\begin{array}{l}\text { LJ, LJ+P* } \\
\text { SKL* } \\
\text { SKS, SKL* } \\
\text { LJ, LJ+P, SKL* } \\
\text { LJ, LJ+P, S7H11, SKS, SKL* } \\
\text { LJ, LJ+P, SKL* + SKL+ } \\
\text { All }\end{array}$ & $\begin{array}{l}34 \\
48 \\
51 \\
52 \\
52 \\
53 \\
53\end{array}$ & $\begin{array}{r}64 \\
91 \\
96 \\
98 \\
98 \\
100 \\
100\end{array}$ & $\begin{array}{r}43 \\
7 \\
7 \\
45 \\
45 \\
54 \\
54\end{array}$ & $\begin{array}{r}34 \\
7 \\
4 \\
5 \\
2 \\
5 \\
2\end{array}$ \\
\hline
\end{tabular}

* No treatment with acid before culture of CSF, pus. Acid pretreatment for other specimens.

† For tissues and fluids only, without acid treatment.

Table 3. It is evident that the SKS and SKL media were considerably less often contaminated than the $\mathrm{LJ}$ and $\mathrm{LJ}+\mathrm{P}$ slopes. S7H11 slopes may have been even less often contaminated than SKS and SKL bottles, though with untreated tissues and fluids the differences betwen S7H11 slopes and SKS bottles (specimens contaminated on S7H11 only 1, SKS only 5) and between S7H11 slopes and SKL bottles (S7H11 only 1, SKL only 5) do not reach statistical significance. The inoculum added to the S7H11 slopes was, of course, much smaller than that added to the Kirchner medium bottles. Since cultures of 14 tissue and fluid specimens inoculated without previous acid decontamination were contaminated in SKS and SKL media, as compared to none that had been decontaminated $(p<0 \cdot 001)$, treatment with acid added to the protection provided by the selective antibiotics in preventing contamination.

\section{CHOICE GF CULTURE MEDIA}

The results that would have been obtained with various combinations of media are shown in Table 4 . Use of the $\mathrm{LJ}$ and $\mathrm{LJ}+\mathrm{P}$ slopes alone would have yielded only $34(64 \%)$ of the 53 positive specimens and 34 specimens contaminated on both slopes. In contrast, a single SKL bottle inoculated with each specimen would have given $91 \%$ of the positives and been contaminated with seven specimens. Adding a second Kirchner bottle (SKS) increased the yield of positives to $96 \%$. The addition of the two Löwenstein-Jensen medium slopes, so that $\mathrm{LJ}$, $\mathbf{L J}+\mathbf{P}$ and SKL were inoculated with every specimen, gave $98 \%$ of the positives. The use of all five media for each specimen would not have improved positivity though the number of specimens yielding total contamination would have fallen from five to two. Perhaps the best compromise between efficiency and the need for economy in media would have been provided by inoculating all specimens onto $\mathrm{LJ}, \mathrm{LJ}+\mathrm{P}$ and SKL, (CSF and pus without, and other specimens with previous acid decontamination), while tissues and fluids would also be inoculated without acid treatment into a single SKL bottle. This procedure would have yielded all 53 of $\vec{\omega}$ the positive cultures and all media would have been contaminated by only five specimens.

\section{Discussion}

In this two-year study, a number of additional media $\bigcirc$ were inoculated as well as the conventional two slopes of LJ medium. To each pair of these slopes was added two bottles of selective Kirchner medium and a slope of 7H11 medium, as well as the direct inoculation of tissues and fluids into selective media in addition to their culture after acid treatment on all of the media. These additional media increase 8 the number of specimens yielding a culture of tuberculosis from 34 to 53 and decreased the number of specimens with all media contaminate from 34 to only two. Most of these benefits could have been obtained by the far simpler procedure of including a single selective Kirchner medium bottle with each set of Löwenstein-Jensen medium slopes, the number of positive specimens decreasing by only one to 52 and the number with completely contaminated cultures rising from two to five. If tissues and fluids had also been inoculated untreated into a single bottle of selective Kirchner medium, the yield of positive cultures would have risen by one to 53 and the completely contaminated specimens would have remained at five.

In an earlier study comparing culture media inoculated with the same volume of sputum homogenate, " the percentage of specimens yielding contaminated cultures was far higher in Kirchner medium without added antibacterial drugs than on LJ slopes. However, the contamination rate for $\mathrm{Kir}-$ chner medium with 100 units/ml penicillin $(5.7 \%)$ was lower than for LJ slopes (10\%) and the propor.tion of positive cultures on the Kirchner + penicillin medium (22\%) was slightly higher than on LJ slopes $(17.5 \%)$. In the present study, the advantages shown by the selective Kirchner medium, confirming earlier findings, ${ }^{67}$ were more substantial. The lower 
contamination rate appears due to more effective prevention of contamination by the antibiotics. The higher yield of positive cultures is likely to have resulted mainly from the addition of larger volumes of specimens to the fluid medium than would be possible to slopes of solid medium. In our experience, large inocula of tissues or pus often inhibit the growth of tubercle bacilli on solid medium. Fluids are usually not inhibitory, but are difficult to add to slopes of solid medium, and bacilli out of contact with the slope might not have optimal nutrition.

Although the results with $\mathrm{LJ}$ medium slopes were greatly inferior to those with selective Kirchner medium alone, there are two reasons for continuing to use the egg-medium slopes. First, growth suitable for identification and sensitivity testing is obtained more rapidly on the solid media. Secondly, some species of mycobacteria, including those causing opportunist infections, are inhibited by the antibiotics in the selective medium. ${ }^{5}$ Because of this problem, McClatchy ${ }^{12}$ reduced the concentration of carbenicillin from $100 \mathrm{mg} / 1$ to $50 \mathrm{mg} / \mathrm{l}$ and found less inhibition of $M$ intracellulare, $M$ kansasii and $M$ scrofulaceum. Although the modified selective medium was more efficient than $7 \mathrm{H} 11$ medium without antibiotics, no comparison of the media with $50 \mathrm{mg} / \mathrm{l}$ and $100 \mathrm{mg} / \mathrm{l}$ carbenicillin was done. These authors recommend, as we do, additional nonselective media. We suggest a standard set of two $\mathbf{L J}$ medium slopes, one with and one without added pyruvate, and a single bottle of selective Kirchner medium. Pus, pus swabs and CSF specimens should be inoculated into this set without decontamination. All other specimens should be decontaminated with $\mathrm{H}_{2} \mathrm{SO}_{4}$ before inoculation into the set. It might be worthwhile inoculating tissues and fluids into a single bottle of selective Kirchner medium without previous acid treatment, but the expected gain in efficiency is small. This standardised procedure is much simpler and probably more efficient than an alternative method in which the extent of possible contamination and therefore the need for acid treatment is assessed by first examining a direct Gram-stained smear of the specimen before culture is undertaken. ${ }^{3}$

\section{References}

${ }^{1}$ Medical Research Council. National survey of tuberculosis notifications in England and Wales 1978-9. Br Med J 1980;281:895-8.

${ }^{2}$ Allen BW, Darrell JH. Extrapulmonary tuberculosis: a potential source of laboratory-acquired infection. J Clin Pathol 1981;34:404-7.

${ }^{3}$ Marks J. Ending the routine guinea-pig test. Tubercle 1972;53:31-4.

4 Mitchison DA, Allen BW, Lambert RA. Selective media in the isolation of tubercle bacilli from tissues. J Clin Pathol 1973;26:250-2.

${ }^{5}$ Mitchison DA, Allen BW, Carrol L, Dickinson JM, Aber VR. A selective oleic acid albumin agar medium for tubercle bacilli. $J$ Med Microbiol 1972;5:165-75.

${ }^{6}$ Mitchison DA, Aber VR. Culture of specimens other than sputum for Mycobacteria. J Clin Pathol 1974;27:883-7.

' Allen BW, Mitchison DA, Darbyshire J, Chew WWK, Gabriel M. Examination of operation specimens from patients with spinal tuberculosis for tubercle bacilli. J Clin Pathol 1983;36:662-6.

' Cruikshank R, Duguid JP, Marmion BP, Swain RHA. Medical microbiology. Vol. II. 12th ed. Edinburgh: Churchill Livingstone, 1975: 119.

' Canetti G, Fox W, Khomenko A, Mahler HT, Menon NK, Mitchison DA, Rist N, Smelev NA. Advances in techniques of testing mycobacterial drug sensitivity, and the use of sensitivity tests in tuberculosis control programmes. Bull WHO 1969;41:21-43.

${ }^{10}$ Medical Research Council. Co-operative controlled trial of a standard regimen of streptomycin, PAS and isoniazid and three alternative regimens of chemotherapy in Britain. Tubercle 1973;54:99-129.

" Public Health Laboratory Service. Cultivation of Mycobacterium tuberculosis. Part VI - The choice of culture media for the isolation of tubercle bacilli from sputum. Mon Bull Min Health 1958;17:112-8.

${ }^{12}$ McClatchy JK, Waggoner RF, Kanes W, Cernich MS, Bolton TL. Isolation of mycobacteria from clinical specimens by use of selective 7H11 medium. Am J Clin Pathol 1976;65:412-5.

Requests for reprints to: Professor DA Mitchison, Department of Bacteriology, Royal Postgraduate Medical School, Ducane Road, London W12 0HS, England. 